\title{
Professionalism: An Imperative for Ethical Practice of Advertising in Nigeria
}

\author{
Godswill O. Okiyi, Chioma Eteng-Martins \\ Federal Polytechnic Nekede, Owerri, Nigeria
}

\begin{abstract}
The practice of the advertising profession in Nigeria has grown proportionally since the first recognized agency was established in 1928 till date. Prior to the enactment of Decree 55 of 1988, as amended by Decree 93 of 1992 which gave statutory rights to advertising, the profession witnessed the incursion of quacks who engaged in unethical activities through the content of their advert copy and relationships with clients, the media, and contractors. However, Advertising Practitioners Council of Nigeria (APCON) has greatly stemmed quackery in the practice of advertising through the enabling laws of authority it has, and the emergence of educated practitioners who are obliged to undergo training and abide by the ethos of advertising practice. Professionalism as laid down by APCON, the statutory body has also created the framework through which advertising can be practiced as a profession, as much as self-regulation has also brought in much needed sanity into its practice.
\end{abstract}

Keywords: professionalism, ethics, advertising, quackery

To enable us appropriately to address the role of professionalism in ensuring the ethical practice of advertising, it is necessary to examine some definitions, which will provide a lead into what determines advertising, actions, and activities that make for ethical practice of the profession and also the negating impacts of being unethical. Advertising has many definitions to suit all intents and purposes. Advertising involves a group of activities or processes carried out to send information about a product or service with intent to make known, convince and persuade the specific audience to use the same, while pointing to the specific organization or entity whose wares are on display, using conventional and unorthodox channels of communication to achieve the objectives. According to Advertising Practitioners Council of Nigeria (APCON) News (1997), advertising is a form of communication through the media about products, services, and ideas, paid by an identified sponsor. According to Bovee and Arens (1986), advertising is the non-personal communication or information, usually paid for and identified with a known sponsor through the various media. The American Marketing Association in its widely accepted definition says that "Advertising is any paid form of non-personal presentation and promotion of ideas, goods, and services by an identifiable sponsor". While to Lew Slade (1998), a former African Regional Director of Ammirati Puris Lintas, South Africa, an advertising multinational, "Advertising is the means by which the producer of a product or service informs his potential

Corresponding author: Godswill O. Okiyi, B.A., M.A., Ph.D., Mass Comm (in view), Dip. in advertising (APCON), Department of Mass Communication, Federal Polytechnic Nekede, Owerri, Nigeria; research fields: public relations/advertising, advocacy communication. E-mail: okiyigodswill@hotmail.com.

Chioma Eteng-Martins, B.A., M.A., Mass Comm (in view), Department of Mass Communication, Federal Polytechnic Nekede, Owerri, Nigeria; research fields: broadcasting and development communication.E-mail: ecchioma@gmail.com. 
consumers as to why, how, and when they should buy that product or service". According to Solaru (1994), good advertising says the right thing about the right product in the right way to the right people at the right time and in the right place. Some basic elements which can be taken from these definitions are that adverts are messages which are transmitted using what is considered appropriate channels (media) by the sponsors of the messages to some specific target audience (people and markets) whom they believe will use such products and services. Added to these are the individuals or professionals who create these messages, negotiate with the media owners and also other suppliers and contractors such as printers, owners of hoardings for outdoor advertising, modeling agencies, and film producers to shoot commercials and also studios where jingles are produced. It may be suggested that without this set of people, the practice of advertising may be disjointed and sloppy without proper coordination of the various segments which make for good advertising and monitoring. Advertising is a creative business and as Okigbo (1999) notes, being service oriented, it can only thrive and perpetuate itself if it builds a reserve of professionals who have the best developed creative and innovative ideas and are technically and intellectually equipped to appropriately react to the ever changing environment. Here is where the crux of the problem lies, in a bid, to be creative and also get the target consumers to buy a product, or use a service, these professionals or those who are not burdened by regulations may tend to ignore what they should truthfully state, albeit in a creative manner.

Basically advertising as a term came from the Latin word ad vertere, which means "to turn the mind toward a product". The intention here is to turn or direct a person's mind toward a specific product, service, or idea. In this case, it includes the means (creative processes) or channels of letting a person know about that good or service and persuade the person to use such. This is the place where creativity comes to play a major role. According to Doghudje (1992), creativity means the ability to put together common sounds, words, or pictures in a unique way. It means to put common things in an uncommon way. While to Arens (2002, p. 378), creativity involves two or more previously unconnected objects or ideas into something new. This is the point where issues of professionalism in the practice of advertising emerges as such is the crux for ethics and the practice of self-regulation, besides the application of statutory codes to guide the profession.

\section{An Overview of the Development of Advertising in Nigeria}

Advertising has existed in Nigeria in one form or another in pre-colonial societies. Different forms and channels have been used to create and pass messages amongst the audience members who dwell in pre-literate societies. Through different symbols, codes, and the employment of sales persons, information about the availability of goods and services was done under acceptable and universally recognized codes in these communities. With colonialism and the amalgamation of the country in 1914, there was the introduction of a uniform monetary system, which led to commercialization and the emergence of new merchandise centres. These led to the development of formal advertising which began with the West African Publicity Limited in 1928, that later became known as Lintas. This also led to the proliferation of advertising agencies which without control encouraged sharp and unprofessional practices. Unethical practices carried out by such agencies tarnished the image of the advertising profession at the time. Another factor that enhanced the growth and development of advertising is the emergence and growth of media outlets, and the development of satellite and cable channels of communication in recent times. With the indigenization of foreign companies in the 1970s, advertising agencies left in the hands of Nigerians, and by the 1980s and 1990s, advertising had flourished and became recognized as a profession through legislations and statutory rights. Also, the sector had become 
defined along sectoral lines as there are APCON, AAAN (Association of Advertising Agencies of Nigeria), ADVAN (Advertisers Association of Nigeria), NPAN (Newspapers Proprietors Association of Nigeria) and the emergence of other groups to ensure sanity and order in the practice of the profession. According to Akinwunmi (2008), a former President of AAAN and Chairman of APCON, in the last five years, the number of AAAN agencies has grown by over $30 \%$. Billings have also climbed with the highest billing agency group doing over N6 billion. Industry billing has also climbed substantially to over N50 billion. The advertising sector has witnessed phenomenal growth which has seen the diversification of activities to the second line agencies, independent media management, direct marketing, experiential marketing, public relations, printing, and outdoor activities. From the above, it can be deduced that indeed advertising has grown to a large extent and this calls for restraint and professional conduct in guiding the practice of the activities. From the observations made by Okigbo (1999) as the practice has grown, there is also the need for a creative and technical pool of professionals to see that the business will continue to grow and perpetuate itself. Professionalism and statutory controls are expected to make advertising practitioners responsible and responsive to the needs and expectations of Nigerians in relation to their practice which include their sourcing and relationship with clients, proper treatment of advert copy for products, and services to be legal, clean, honest, and truthful. Related to this is the need to be properly informed about the goods and services which they are marketing.

\section{Conceptual Framework}

Citing Merrill (1974) and Fab-Ukozor (2005) note that there are dominant theories of ethics which are absolutist, relativist, teleological, deontological, legalistic, antinomian, and situational. These theories give reasons why human beings take whatever moral decisions they arrive at in their relationships with other people. The advertising practitioner who is led by the absolutist theory accepts in principle that there are moral universals that form the basis of a universal and eternal code in practice such as truthfulness, decency, legality, and honesty. For the relativist, the argument is that moral values change with culture, time, and circumstances, while teleology affirms that the yardstick for measuring rightness and wrongness of an action depends on the consequences which that action will give rise to. The deontologist holds a reverse view in the sense that the practitioner accepts in principle that the judgment of whether an action is good or bad should be based on the action itself but not the consequence. The legalistic or code of ethics is an absolute or objective ethical system which is based largely on tradition, social agreement, or a firm moral code, however, the antinomian is against standards, laws, principles, and precepts. Finally, the situational ethicist is led by the traditional code of ethics but moves away from it whenever he or she thinks, it is best to do so in the publics' interests.

On the other hand, ethics refers to doing what is right or wrong. To behave ethically is to behave in a manner that is consistent with what is generally considered to be right or moral. Ethics are moral principles and values that govern the actions and decisions of an individual or group (G. Belch \& M. Belch, 2001). Ethical advertising means doing what the advertiser and the advertiser's peers believe is morally right in any given situation. An advertiser can act unethically or irresponsibly without breaking any laws. Citing Ivan Preston, Arens (2002) says that "ethics begin where the law ends". In advertising, ethical considerations would be those conducts, aptitudes, or behaviours that are displayed and deployed in the carrying out of the practice which are morally right and reflect moral principles in them. Ethics consists of certain rules and standards of conduct recognized in building a professional body or association. These standards and conducts could be seen as 
actions or manner of conducting, directing, managing, or carrying on in a specific sphere. To be ethical, it requires the need for the professional to behave in a way and manner which is morally right, in a right behavior and showing a right aptitude that shows leadership.

Finally, in the conceptual framework that defines the work, professionalism refers to the skills or qualities of a profession or of its members; or great skills and competences that can be associated with a profession (Oxford Advanced Learner's Dictionary). As Okigbo (1998) observes, "A profession means a body of people who perform similar functions and are held together by a common bond of association arising from their performance of similar tasks, common identifiable norms, values, and rules". Citing McLeod and Hawley (1964), Okigbo continued that the former developed an instrument for measuring professionalism among newsmen and found that professional journalists generally are more concerned with ethical standards, are more educated, more critical of their own employers, more independent on the job, and less likely to take a non-journalism job. They are also less concerned with money and prestige. Further, the American Institute for Advertising Ethics of American Advertising Federation: Reynolds Journalism Institute observes that the one constant is transparency, and the need to conduct ourselves, our businesses and our relationship with consumers in a fair, honest, and forthright manner. And the body further observed that inspired advertising professionals will practice and benefit from enhanced advertising ethics.

From the above, it can be agreed that the defining line between professionalism and quackery in any sector is by abiding by the ethics or moral codes of conduct guiding it. It also reveals that the concept of ethics has different perspectives from which it can be interpreted. Generally, it is mainly professionals who are guided by the ethics of their professions and education.

\section{Professionalism in Advertising Practice}

With the emergence of formal advertising in 1928 in Nigeria, there was also the growing number of individuals who took advantage of the bludgeoning commercialization in the country to set up their own advertising practice. Unlike how the practice was carried out by West African Publicity Limited which was affiliated to advertising bodies in London, the same could not be said for the numerous local agencies that flooded the Nigerian landscape at the time. This led to sharp practices, fraud, and unethical practices in the activities and processes of advertising that called for regulations and statutory controls. It was expected that with regulations: Statutory regulation or self-regulation will bring about the maintenance of standards, emergence of credit-worthy agencies, and prevention of the mushrooming of agencies, shutting out of quackery. With time and the setting up of self-regulatory bodies such as Association of Advertising Practitioners of Nigeria (AAPN, now AAAN), ADVAN, NPAN, and the promulgation of the APCON in 1988 by Decree 55 as amended by Decree 13 of 1992, now Act No. 116 of 1993 which effectively made advertising a profession. Whereas, AAAN is a self-regulatory body to checkmate the activities of members of the body, APCON is backed by statutory rights of the Federal Government of Nigeria and can ensure control and compliance through the law, it can also exert punishment on erring members or quacks in the profession. As Divinsky (2008) observes in many countries, there are official organizations mandated to vet advertising to ensure it is not offensive, deceitful, and culturally distasteful. As such, organizations and practitioners are led by the guidelines which these statutory bodies have put in place. Practitioners are also expected to be self-regulated as to be seen to be accountable and truthful to gain the prospects which they are reaching out to. 
The question then is what makes for professionalism and its attendant inputs in the practice of advertising. Okigbo citing Hohenburg (1987, p. 16) from his book The Professional, the qualifying qualities of professionalism have four essential ingredients. For those who want to make a beginning in journalism, of the media involved, the minimum requirements may be summed up as follows: a thorough education, sound training, and a willingness to accept discipline; familiarity with the basic skills of a journalist; and the will to work at tasks that are sometimes frustrating and seem unrewarding at the outset and a deep respect for one's personal and professional integrity. This much can be said for advertising because as the American Institute for Advertising Ethics surmise in its First Principle, advertising, public relations, marketing communications, news, and editorial all share a common objective of truth and high ethical standards in serving the public, which is seen in The Journalist's Creed. Invariably, in describing the qualities of professionalism in journalism, the same is attributable to advertising practice. For the advertising professional, it will be expected that he or she will be characterized by the following: a proper education and discipline; appropriate skills; non-material ego drive and personal and group integrity (Okigbo, 1998). Ugwuezuonu (1998) in defining a profession cites Flexner who says that there are six distinctive criteria of a profession: It is based on intellectual activity; requires from its members the possession of a considerable amount of knowledge and learning; has definite and practical purposes; has certain techniques which can be communicated; has an effective self-organization and is motivated by a desire to work for the welfare of the society. Citing Cart-Saunders and Wilson, he continues that the application of an intellectual technique to the ordinary business of life acquired as the result of prolonged and specialized training is the chief distinguishing characteristic of the professions. Ugwuezuonu (1998) citing Nwosu, Ikechukwu, PhD, the former Chairman of the African Council of Communication Education (ACCE), states that being professional refers to the ideology and related activities that can be found in any occupational group whose members aspire to improve professional status. It bestows pride on members of the group, and makes them stand out in the crowd of occupational groups. It also brings with it a lot of duties, responsibilities, and societal expectations which keep the true professionals always on their toes, on their guard always ready to fight for and protect the ideals for which the profession is known. For advertising practice therefore, certain ingredients can be deduced from the positions of the various authors: There is the need for the acquisition of a higher education above certain minimums, it is expected that there should also be training and imbibing of skills in different aspects of the business. There is the need to identify with the occupational sector which defines the profession. Membership of the statutory body and other relevant sectoral associations is requisite for the advertising professional. Also, there is the need to be recognized as being a member of that group through the exhibition of certain distinguishing qualities that stands the professional out from the quack. It is also expected that the advertising professional should exhibit a high sense of integrity and high moral conducts which are stated within the ambit of the rules of the profession.

\section{Ethical Considerations Guiding Advertising Practice}

Ethics consists of certain rules and standards of conduct recognized in building a professional body or association such as advertising. According to Ayozie (1998), usually a profession provides a code of ethics and conduct to guide members in their practice. Assimilation of the requisite body of knowledge or education qualifies one to practice a profession, while the challenges and demands faced by the profession dictate the substance of such education. To be ethical, a professional or an occupational group is expected to operate within standards of conduct which could be seen as action or manner of conducting, directing, managing, or 
carrying on in a specific sphere (Okiyi, 2007). Ethical considerations in advertising imply having a right aptitude that indicates leadership. It reveals or shows the right disposition or an exemplary aptitude which is morally right while engaging in advertising practice. Advertising ethics point to the set of principles which uphold the concept or idea of decency, honesty, truth, and legal and frowns at deception, falsehood, and fallacy. As Levick, Jeff, the President of Global Advertising \& Strategy, AOL (AOL Advertising) (2011) observes, it is critical for the industry to acknowledge and accept that advertising is commercial information that must be treated with the same accuracy and ethics as editorial information.

The need for professionalism through the implication of abiding by ethics guiding advertising practice is intrinsic. This is so because advertising is involved in the building up of dynamic economic systems and also drives economies through its activities. Advertising also uses enormous human and material resources to achieve its purposes. A successful advertisement impacts economically, socially, culturally, and morally. As Pope John Paul VI remarks, "No one now can escape the influence of advertising". People who are not themselves exposed to particular forms of advertising confront a society, a culture, and other people, affected for good or ill by advertising messages and techniques of every sort. As the Pope further observes, there is nothing intrinsically good or intrinsically evil about advertising. It is a tool, an instrument: It can be used well, and it can be used badly. Advertising at times has beneficial results and also negative harmful impact on individuals and society. As he summed it up,

If harmful or utterly useless goods are touted to the public; if false assertions are made about goods for sale, if less than admirable human tendencies are exploited those responsible for such advertising harm society and forfeit their good name and credibility.

Further, Nzeribe (2012) observes that where a consumer does not get the total picture, the advertisement is deceptive or there is a deliberate intention to deceive. There is therefore the need to ban "weasels" and dangling comparisons and to substantiate the product claims. Such subjective claims as "a beautiful furniture", "just like mama's cooking", and "great-tasting coffee" cannot really be substantiated. In the realm of an objective or competitive claim, research must be available to support it. This captures the essence of ethics in advertising and other processes involved in it. Advertising aims to inform persuade and motivate people to act in certain ways, buy certain products or services, and patronize certain institutions or organizations. In carrying out these tasks, how they are achieved and the motives of all concerned including the advertiser, the practitioner and media are all predicated on the platform of ethics or in conducting such within the principles and precepts guiding the advertising profession. Ethical considerations go beyond operating within the ambit of the law or statutory control, or acting in compliance to what the laws guiding advertising says, it is rather abiding and maintaining a self-imposed respect for integrity by the advertising practitioner or the occupational group.

\section{APCON and Its Role in Professionalizing Advertising}

APCON came into existence by the enactment of Act No. 55 of 1988 later amended by Act No. 93 of 1992 and Act No. 116 of 1993. The enabling laws mandated APCON to control advertising in all its aspects and ramifications. The Advertising Standards Panel (ASP) which is one of three statutory standing committees of APCON was set up by Act No. 93 of 1992 with the primary assignment of ensuring that advertisements are prepared with a sense of social responsibility and in adherence to the codes of practice expected of practitioners and users of advertising services. Advertising in Nigeria is statutorily regulated by the Advertising Practitioners 
Council of Nigeria Act. The act established the Advertising Practitioners Council of Nigeria and is divided into six parts: Part 1: establishes the council, its functions, and composition; Part 2: deals with registration, including the process of becoming a member of the advertising profession; Part 3: deals with training, including the approval of any course of training which is intended for persons seeking to become members of the profession; Part 4: deals with the privileges of registered persons and offences by unregistered persons; Part 5: deals with discipline; and Part 6: deals with supplementary provisions. For the intent of this paper, Part 2 is pertinent as it deals with the requirements of becoming a practitioner or a professional (advertitioner?). Parts of this include having the name of the person and qualifications in the register. She/he is also required to pay fees according to their category of registration and yearly membership fees. The three grounds which a member's name may be removed from the register are: death, insanity, and gross misconduct. With APCON, advertising practitioners are to be registered or licensed to become professionals. This licensing is premised on three pillars which are: (1) training (skills, praxis, and qualifications); (2) code of practice/ethics; and (3) integrity (respect and service) (Okigbo, 1998). APCON's responsibilities stem from these three themes and are broadened into five functions which are: (1) determining what standards of knowledge and skills are to be attained by persons seeking to become registered as members of the advertising profession and reviewing those standards from time to time; (2) regulating and controlling the practice of advertising in all its aspects and ramifications; (3) conducting examinations in the profession and awarding certificates or diplomas to successful candidates as and when appropriate; (4) privileges and appointment of registered persons of the Council and Punishment and Offences of unregistered persons; and (5) disciplinary actions and penalties for unprofessional conducts by persons.

This overview of APCON's responsibilities reveals that being ethical and maintaining professionalism is central to the activities of practitioners of advertising in Nigeria. This is seen in the second and third themes of the pillars of the organization and explained in the second responsibility noted above. The implication of the Advertising Standards Panel charged with the duty of ensuring that advertisements conform to the laws of the Federal Republic of Nigeria as well as the codes of ethics of the advertising profession (APCON, 2003, p. 27). APCON's Code of Ethics is a comprehensive book of rules covering every aspect of advertising in Nigeria, ranging from tobacco and alcoholic products to politics, banking services, and medicine. These codes are voluntary and do not have the force of law, and cannot be penalized. This is where integrity which determines conduct and professionalism comes into play in advertising practice. These codes can be split into four parts and include the following: (1) advertising is to be legal, decent, honest, truthful, and respectful of Nigeria's cultures; (2) advertising is to be prepared with a high sense of serious responsibility and should not show disregard for the interest of consumers and the wider Nigerian society; (3) it should conform to the principles of fair competition generally accepted in business, and fair comment expected in human communication; and (4) it should enhance public confidence in advertising. Commitment to these codes by practitioners will reveal adherence to the ethics guiding advertisement without being force by the law, and reveal professionalism by the practitioner.

From the ongoing, it is seen that the advertising sector has in place structures which will enhance professionalism, and the central body responsible for this is APCON which has been enabled by law to control and sanitize the practice of advertising as much as it is possible. Working in tandem with sectoral groups like AAAN, ADVAN, NPAN, OOAN, BON, etc., efforts are carried out regularly to achieve this. 


\section{Conclusions}

In the course of this work, the authors examined the development of the advertising industry in Nigeria, and also traced the growth of the industry to the point where statutory and regulatory associations and organs became established. The authors also provided conceptual framework through which the ideas and concepts used in the paper were done. Further, the recognition of advertising by the Federal Government of Nigeria through Act No. 55 of 1988 was amended by Act No. 93 of 1992 and later Act No. 116 of 1993. This is further enhanced by the setting up of three statutory committees, one of which is the Advertising Standards Panel. In being professional, advertising practitioners are expected to abide by certain rules and regulations guiding advertising. Besides, they are also expected to embark on training and acquire different levels of education which will enable them to become professionals of the sector. Besides, practitioners are also expected to register and pay yearly fees to enable them practice. Again, there are codes of ethics which advertising practitioners are expected to abide by. Different sectoral groups within the advertising industry are obliged to be guided by these codes. By carrying out practices which are self-regulated, and meet with the demands of the codes of ethics besides the statutory regulations will build professionalism in the advertising industry. Finally, the words of Okigbo in Nzeribe (2012) in his foreword of the book of a late icon of advertising practice in Nigeria, Dr. May Nzeribe is pertinent as he observes that ethics is at the heart of advertising practice which must be regulated for it to maintain its unique relevance in our society.

\section{References}

Akinwunmi, L. (2008). Who is killing advertising: The advertiser, the agency, the media (or the regulators)? Proceedings from APCON Seminar. March 28, Lagos, Nigeria.

Alao, K., \& Okiyi, G. (1989). Self-regulation by advertisers and advertising agencies in Nigeria. Class Project. Ibadan: U.I.

APCON (Advertising Practitioners Council of Nigeria). (2003). Nigerian advertising laws, rules and regulations. Lagos: APCON Secretariat.

APCON News. (1997). Quarterly newsletter of the Advertising Practitioners Council of Nigeria. Lagos: APCON Secretariat.

Arens, F. W. (2002). Contemporary advertising. New York: Irwin/McGraw Hill Companies.

Ayozie, D. O. (1998). Professionalism and statutory control of advertising in Nigeria. The 5th Advertising Day Programme. Lagos: APCON Secretariat.

Belch, G. E., \& Belch, M. A. (2001). Advertising and promotions. New York: Irwin/McGraw Hill Companies.

Bovee, L. C., \& Arens, F. W. (1986). Contemporary advertising. Homewood, I.L.: Richard D. Irwin.

Divinsky, P. (2008). How is advertising influenced by ethics? Retrieved from http://www.cnn.com/2008/BUSINESS/ 07/08/jwt.answer/

Doghudje, C. A. (1992). Creativity in advertising. ADWORLD. Lagos: Zus Bureau.

Fab-Ukozor, N. T. (2005). Ethical responsibility and professionalism in journalism practice: The Nigerian experience. An unpublished conference paper. Makurdi: ACCE.

Hohenberg, J. (1987). The professional journalist. New York: NRW.

Lambeth, E. B. (1986). Committed journalism. Bloomington, I.N.: Indiana University Press.

McLeod, J., \& Hawley, S. (1964). Professionalism among newsmen. Journalism Quarterly, 41, 529-588.

Merrill, J. C. (1974). The imperative of freedom: A philosophy of journalistic autonomy. New York: Hastings House.

Nzeribe, M. N. (2012). Advertising ethics and regulation in Nigeria: The challenges. Ibadan: Feathers and Ink Publishers.

Ojo, T. K. (2007). An assessment of ethical values in the practice of copywriting. An unpublished research project. Iwo: Bowen University.

Okigbo, C. (1998). Professionalism in advertising. The 5th Advertising Day Programme. Lagos: APCON Secretariat.

Okiyi, G. O. (2007). Ethical considerations and patterns of medical advertising in selected newspapers: A content analysis. An unpublished conference paper. Zaria: ACCE. 
Pope Paul VI. (2013). Pontifical Council for social communication ethics in advertising. Retrieved from http://USER/Downloads/ETHICS IN ADVERTISING.htm

Slade, L. (1998). Advertising in a new millennium. APCON News. Lagos: APCON Secretariat.

Solaru, B. (1994). The copywriter. AdNews. Lagos: APCON Secretariat.

Ugwuezuonu, A. N. (1998). Professionalism and statutory control of advertising in Nigeria. The 5th Advertising Day Programme. Lagos: APCON Secretariat.

Uwadiae, N. (2006). Superlative claims in brand advertising: Facts or puffery? ThisDay Newspaper. Lagos: ThisDay Newspapers Publishing Co. 